\title{
How Do You Comprehend Tahilalats Comic?
}

\author{
Herlandri Eka Jayaputri* \\ Yogyakarta State Univesity, Karang Malang, Jl. Colombo No.1, Caturtunggal, Kec. Depok, Kabupaten Sleman, Daerah Istimewa \\ Yogyakarta 55281
}

\section{A B S T R A C T}

This study discusses the use of the cooperative principles and the conversational implicatures in Nurfadli Mursyid's Tahilalats comic. Tahilalats is one comedy comic in Line Webtoon. The comic contains four panels in each episode, and its stories concern social phenomena. However, the readers said that Tahilalats comic was difficult to understand. This was the reason the writer conducted this study, which was an analysis of the use of the cooperative principle in Tahilalats comic. The study aimed at finding the forms of conversational implicature and describing the functions of conversational implicature in the comic. This study was focused on 30 episodes of the comic, and to collect the data the writer used simak and catat techniques (Sudaryanto, 1993). The results are related to the cooperative principle and the conversational implicature. The violation or compliance of the cooperative principles can describe the implicatures in the conversation. The uses of both produce humorous effects because these potentially lead the reader to misunderstand the comic when reading explicitly. However, reading the comic further, the reader will understand the implicit meanings.

\section{A R T I C L E I N F O}
Paper type:
Research Article
Article history:
Received 16 December 2017
Revised 10 August 2018
Accepted 10 August 2018
Keywords:
- Pragmatic study
- Conversational implicature
- Cooperative principle
- Humor and
- Comic

\section{Introduction}

Understanding the meaning of speech is important in various contexts. However, there are times when the interlocutor cannot understand the speaker's meaning because the speaker's meaning is not always explicit but also implicit. Discussing the implicit meaning relates to implicature, which is within the pragmatic studies related to the meaning of language. Implicature concerns an implicit meaning of what the speaker says (Rani, 2006). Implicature is used in both spoken and written discourses.

Novels and comics have meanings and contexts suitable to their settings. Authors usually write their works to express their imagination, ideas, and experiences. The context of a novel is spelled out clearly in the words that describe the situation, whereas the authors of comics write their purposes or meanings in balloon texts. The text and pictures cannot be separated because the pictures illustrate the situation or context. This is the reason the comic reader has to connect the words and pictures so as to know the meanings of the comic.

Nurfadli Mursyid's Tahilalats is a comic in Line Webtoon. Tahilalats has a comedy genre, and almost all episodes in Tahilalats have four panels only. The stories are in daily conversation and concern phenomena occuring in society. This comic is popular in Line Webtoon; Tahilalats has rated 9.69, and the number of the reader is up to 18.8 billion. The comedy featured in this comic is unusual, including communicating implicit meanings, so sometimes the readers have difficulty in understanding the purposes or meanings of the stories. Humor can occur verbally; verbal humor produces a comedy discourse, which is made using linguistic aspects such as sounds, words, phrases, and sentences. In semantic aspects, this can be shown by deviating from rules

*E-mail Addresses: herlandrieka@gmail.com 
or logics. Comedy discourse, such as comic, has a slight difference because it has no sound, and it is related to the context depicted in the comic image. Pictures present the characters, background, situation, and spatial codes which can help the reader to interpret the humor in the comic.

Some studies have used comics as research data. Saputri (2013) is an analysis of the implicatures and inferences in B.P. Habean's school children's humor books. She made an emphasis on the analysis of implicatures in general and inferences. The implications of this research is that the reader should be able to determine the implicatures in the discourse; thus, the reader can conclude utterances that have implied meaning. Another research, entitled Pelanggaran dan Pematuhan Prinsip Kerjasama pada Humor Kureyon Shinchan Volume 3, was carried out by (Nandiwardana, 2016). He analyzed the violation and compliance of cooperation principles. The result showed that the violation maxims could influence the misunderstanding of the readers and this could produce humorous effects. Submissive maxims were usually used to express anger.

This research is focused on the conversational implicature and the use of cooperative principles in Tahilalats comic of the Webtoon Line. The limitation of this research is that the research concerns implicatures in the conversation and the types of cooperative principles in Tahilalats comic. There are several research questions in this study, i.e. (1) what are the types of the cooperation principles in the comic?; (2) what are the forms of conversational implicature in Tahilalats?; and (3) what are the functions of conversational implicature discovered in the comic?. The study is thus aimed at analyzing the types of cooperative principles in the comic, finding the forms of conversational implicature and describing the functions of the conversational implicature.

There are several literature reviews to support the data analysis. The main theory is Pragmatics, which is the study of meaning in relations to speech situations (Leech, 1993). Pragmatics emphasizes the meaning and peech situation. Thus, pragmatics is a branch of linguistics that studies the meaning of the speaker's utterances in certain situations. Pragmatic analysis is focused on conversations that occur between a speaker and the interlocutors. Conversation is spoken between two or more participants, which generally occurs in informal situation. By understanding implicatures, the hearer can comprehend the speaker's utterances.

The term "implicature" is used to refer to what might be interpreted from the speaker's utterance; that the meaning of the utterance is different from what the speaker says. It has an implicit meaning (Brown \& Yule, 1996). The conventional implicature involves the conventional meaning. It depends on special context for interpretation. In addition, it is an aspect of pragmatic study whose primary concern is studying 'the purpose of a speech' according to the context (Suyono, 1990). Implicature is implicit in pragmatic functions, such as speech act (Rustono, 2000). The function is referred to by five speech acts based on Searle's taxonomy (Rustono, 2000). The category of conversational implicatures, according to the pragmatic function, consists of five parts (Rustono, 2000):

a. Representative implicature is to bind the speaker's truth of implicature contained in his/her speech. The functions of a representative implicature are explaining, reporting, showing and mentioning something.

b. Directive implicature is an implicature intended for the listener to act as the speaker's implicature. Directive implicature functions as ordering, begging, demanding, advising, and challenging.

c. Expressive implicature is an implicature functins as an evaluation material of the speech. The implicature functions as praising, thanking, criticizing, and complaining.The commissive implicature is an implicature that binds its speaker to perform an action as in his implication. The functions of the implicature are pledging, swearing, and threatening.

d. The declarative or isbati implicature is an implicature used by the speaker to create something implicated. The implicature is found the acts of deciding, canceling, banning, allowing and forgiving.

Using the principles of cooperation, containing maxims, results in implicature. The use of maxim can grouped into the violation of maxim and the compliance of maxim. This can lead to communicative conversation or misunderstanding. The four maxims of Searle's cooperative principles are the quantity maxim, the quality maxim, the maxim of relevance, and the manner maxim (Grice, 1975). Analyzing maxims is significant because comedy usually seems inappropriate. This is caused by maxim violation or the compliance of maxims.

Western psychology classifies comedy or humor into social, cognition (productive of humor stimuli and the perception of humor), emotional (positive and vocal positive) and vocal-behavioral (laughter and smiling) types (Kazarian, 2011). Humor can be defined as the ability to distinguish aspects of verbal expressions, actions, and movements that are not feasible and funny and then expressed with laughter, smiles or feelings of satisfaction (3abd Al Hamid, 2003 cited in Kazarian, (2011). Therefore, in humor there is a relationship between verbal and context. Humor can appear textually, created by the author through the imagination that appears in 
the form of a real comic or novel. The comedy type in the comic Tahilalats is cognitive because the discourse on the comic forms humor in stimuli and perceptions, which the readers can understand.

\section{Research Method}

This study includes descriptive qualitative method. The subject of this study is Tahilalats, and the researcher focused on thirty (30) episodes of the comic. The data collected using simak and catat techniques (Sudaryanto, 1993). The data were analyzed in three (3) steps. The first step was looking at the use of the speeches in Tahilalats comic. Second, the speech was analyzed using cooperative principles. Finally, the data were categorized based on the form and function of conversational implicature. Then, the result of the analysis was stored in data cards based on the maxims in the conversation of Tahilalts comic and the forms and functions of the conversational implicature.

\section{Result and Discussion}

Concerning the result and discussion, the researcher described the study results in two points. First, the researcher decided the violation or compliance of maxims which occurred in the data. They are the quantity maxim, the quality maxim, the relevance maxim, and the manner maxim (Grice, 1975). Second, the data were described based on the form and function of conversational implicature, viz. (a) representative implicature functions as explaining, reporting, showing and mentioning form, (b) directive implicature is related to asking/ordering, begging, demanding, suggesting and challenging, (c) expressive implicature is concerned with praising, thanking, criticising or complaining, and beefing, (d) commissive implicature concerns promising, swearing, and threatening, and (e) declarative or isbati implicatures relates to deciding, canceling, prohibiting, and allowing (Rustono, 2000). Representative implicature has some functions, such as explaining, reporting, showing and mentioning. The data analysis are as follows:

\subsection{The Representative Implicature}

Data 14. Episode 309

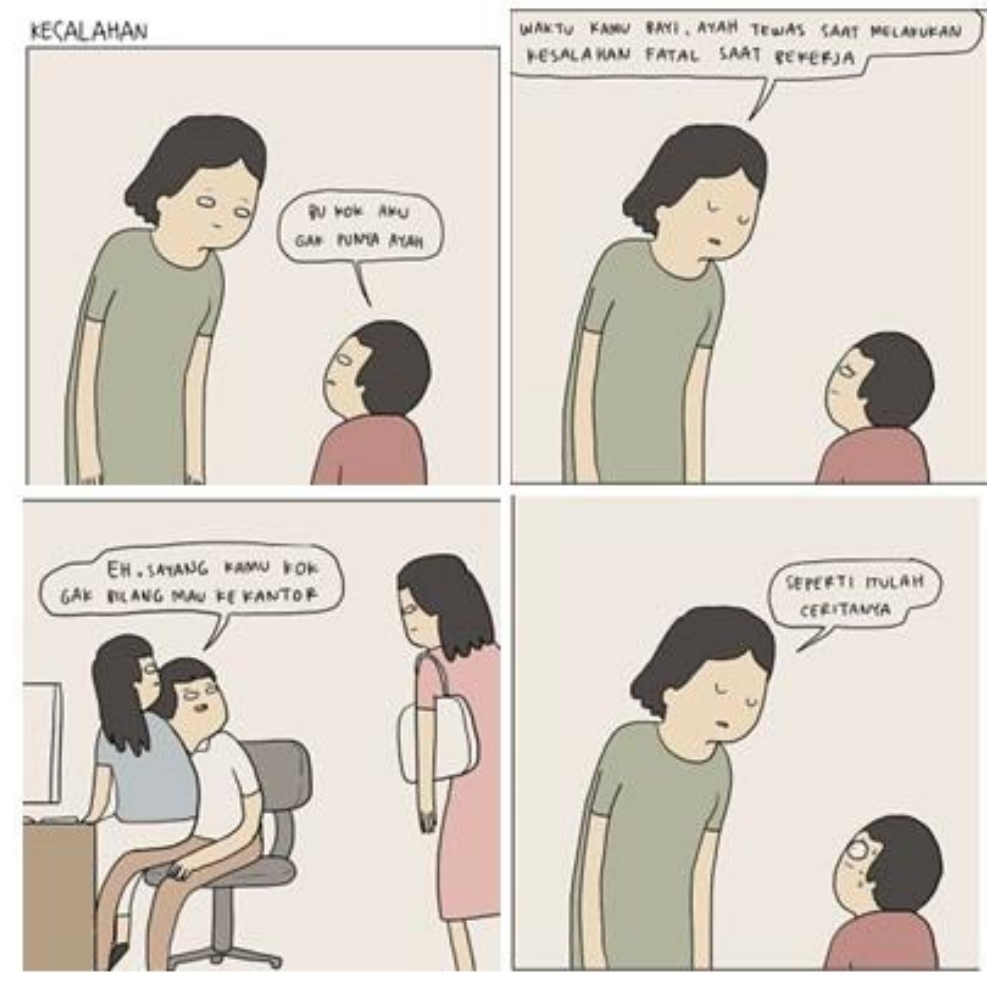

Context : The boy asked his mother where his father was.

Boy $\quad$ : Bu kok aku gak punya ayah (1)

(Mom, why don't I have a dad?) 


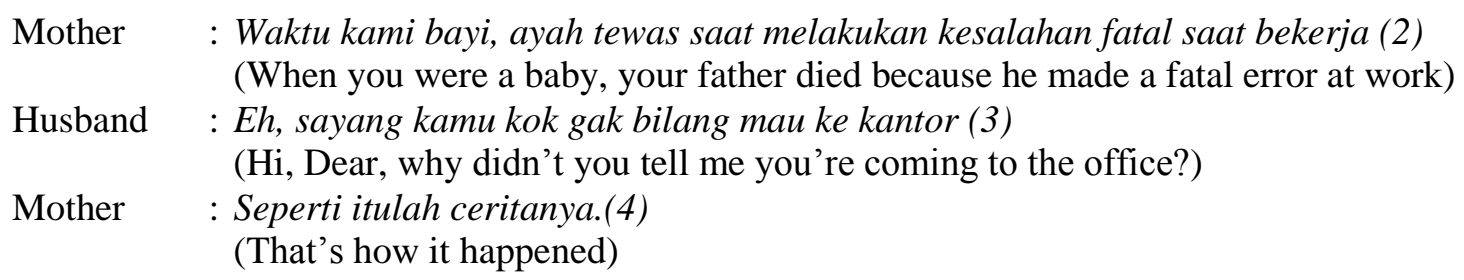

The kid asked his mother why he had no father. The mother replied that his father passed away because he made a fatal error at work. The boy was silent, showing a sad face. After that, the mother remembered the past events when she went to her husband's office. She saw her husband, who was holding another woman in the office. Then, the mother responded "that's how it happened", and her son looked frightened.

The datum broke the manner maxim because when the son asked his mother about his father. The mother only responded that "Waktu kamu bayi, ayah tewas saat melakukan kesalahan fatal saat bekerja (2)" and "Seperti itulah ceritanya (4)". Sentence (2) and (4) showed that the mother did not answer the question clearly. Thus, the information was unclear, and the sentences have an ambiguous meaning, such as he died because of working accident, dismissal from work, or having an affair.

The sentence "waktu kamu bayi, ayah tewas saat melakukan kesalahan fatal saat bekerja (2)" indicated representative implicature. The implicature explained the father's death due to a fatal error; it has multiple meanings, such as working accidents or being fired. However, the picture on the panel three showed that when the mother came to the father's office, he was holding a woman. It explained that his father had an affair with another woman. Thus, the function of the implicature was explaining his father's death due to an affair in the office.

\subsection{The Directive Implicature}

Data 10. Episode 235
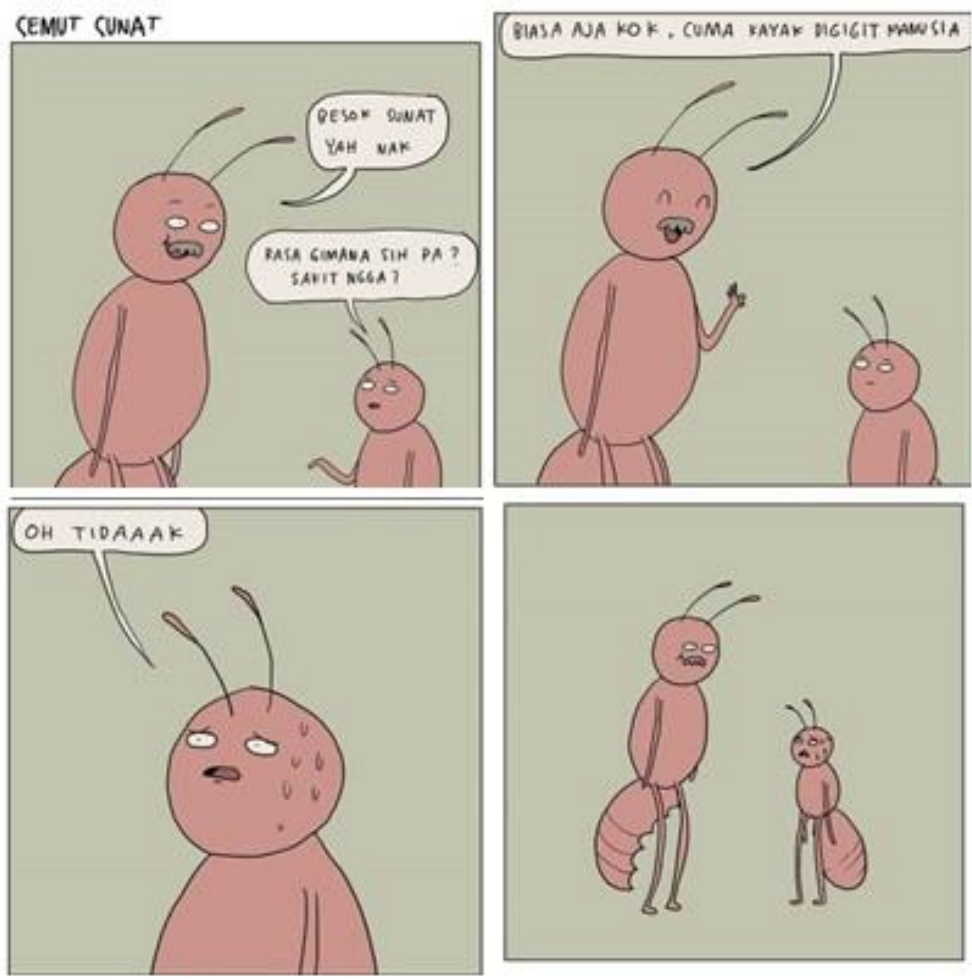

Context : The father asked his son to circumcised

Father : Besok sunnat yah nak (1)

(You circumcise tomorrow, will you?)

Son : rasa gimana sih pa? Sakit ngga?(2)

(How does it feel, Dad?) 
Father $\quad$ : biasa saja kok, Cuma kayak digigit manusia (3) (It's like being bitten by human)

Son : oh tidaaak (4)

(Oh nooo)

The father asked his son to do circumcision to. Before doing the cirsumsion, his son asked the father's circumcision experience. He said that it did not hurt; it was like a human bite. The son inferred that doing circumcision was painful because he saw his father had lost half of his abdomen because of human bite. Thus, the son responded with fear.

In the sentence (2), the son asked how it felt to be circumcised. Then the father answered in sentence (3) and gave a response "Cuma kayak digigit manusia". The datum violated the quantity maxim because the son only asked the feeling of being circumcised, but the answer provided more information than was necessary. If the father had obeyed the quantity maxim, he would have answered "yes or no" to the question.

Sentence (3) "Biasa aja kok. Cuma kayak digigit manusia" is a directive implicature. The implicature was used to ask the son to do circumcision. The fact was that the father did circumsion and lost half of his stomach (abdomen), as was shown in the picture. In addition, the son knew the feeling of doing circumsion through his father's stomach. Thus, the implicature functions as asking his son to get the circumssion.

\subsection{The Expressive Implicature}

Data 2. Episode 27
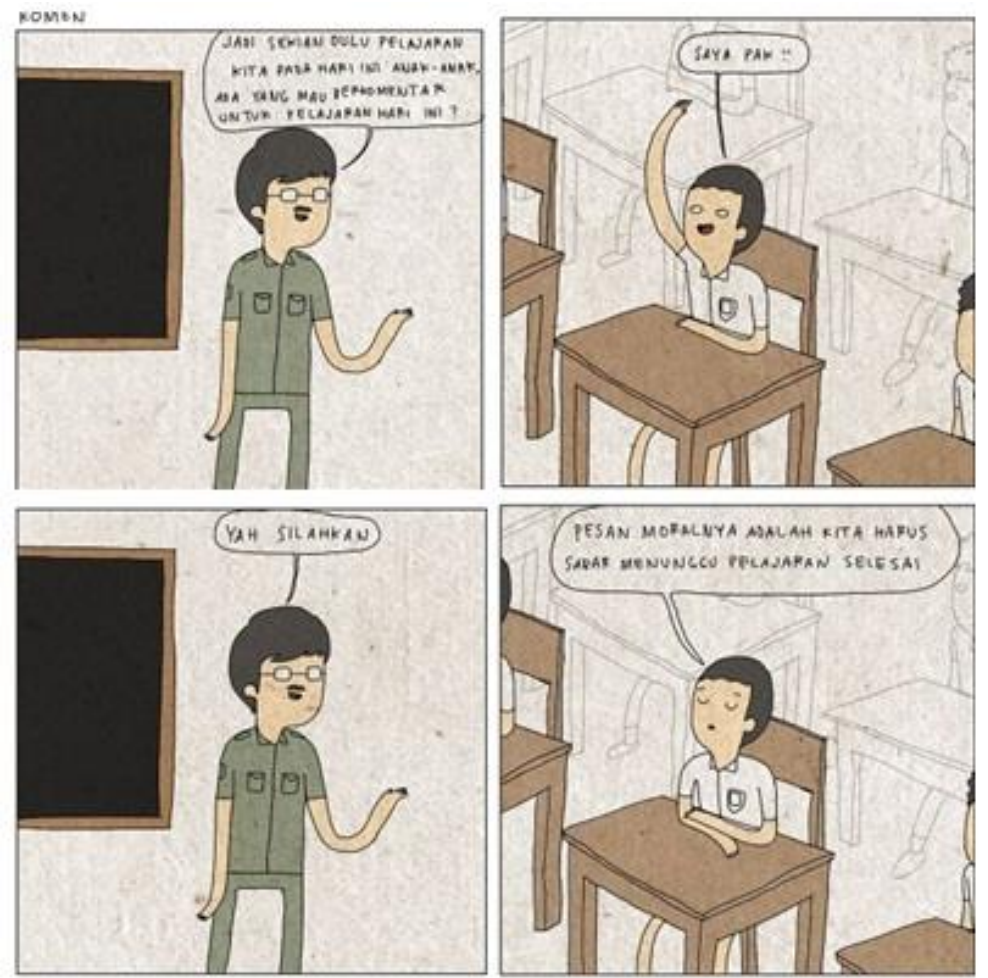

Context : Students were listening to the teacher, and he wanted to dismiss the class.

Teacher : Jadi sekian dulu pelajaran kita pada hari ini anak-anak ada yang mau berkomentar untuk pelajaran hari ini? (1)

(So let's conclude our today's class. Any comments for today's lesson?)

Student : saya pak!!(2)

(Yes, sir!!)

Teacher : yah silahkan (3)

(yes please)

Student : pesan moralnya adalah kita harus sabar menunggu pelajaran selesai(4) (the moral value that is we need to be patient to wait for the class to end) 
The teacher was teaching in the classroom. Before the class was ended, he wanted to hear a comment from his students. One student responded that the moral value of the lesson was that the students had to be patient to wait the class to end. Moreover, in sentence (4), "pesan moralnya adalah kita harus sabar menunggu pelajaran selesai" showed that the situation in the classroom was boring. The data obeyed the quality maxim because the student gave factual information with an emphasis on the words "kita harus sabar menunggu".

The sentence (4) "pesan moralnya adalah kita harus sabar menunggu pelajaran selesai" showed an expressive implicature. The sentence has an implicit meaning, which is beefing about the lesson. It can be defined that the class was so boring that the students wanted to the class to soon finish. Thus, the function of the implicature is beefing about the lesson.

\subsection{The Commissive Implicatures}

Data 19. Episode 368

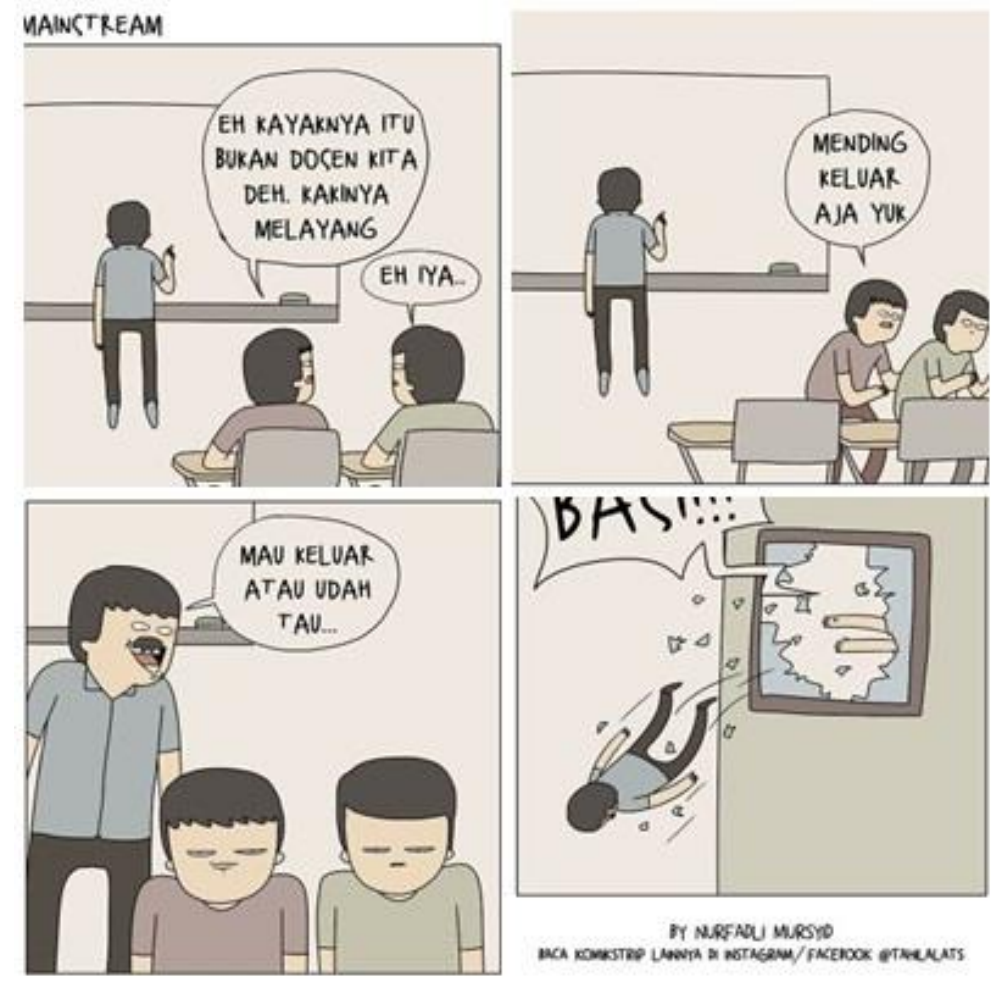

Context : Two students were studying in the class.

Student 1 : Eh kayaknya itu bukan dosen kita deh. Kakinya melayang (1)

(Eh he is not our lecturer. His foot is flying)

Student 2 : Eh iya...(2)

(yes)

Student 1 : Mending keluar aja yuk (3)

(We had better get out of the class)

Lecturer : Maukeluar atau sudah tau (4)

(Want to go outside or you have known it)

Student $1 \& 2$ : Basi!!!

(awful!!)

Two students were studying in the classroom and they knew that the lecturer was not human because his legs hovered. When they wanted to get out of the classroom, the lecturer came and said that "want to come out or already know..". However, the students replied "basi!!". The word basi or awful meant that there were many stories about a ghost lecturer, so they had known about him. 
The datum contravenes the manner maxim because the information was not provided directly. It was shown in the sentence (4) "mau keluar atau udah tau...". The sentence can be meaningful to insinuate that the students were afraid of him. The sarcastic phrase did not illustrate the information directly.

The sentence (4) "mau keluar atau sudah tau" has a commissive implicature because the implicature could influence the partner to do what the speaker said. The phrase showed that the ghost lecturer threatened the students that he was a ghost and asked his students to get out. Thus, the datum functioned to threat the students, who had known that the lecturer was a ghost.

\subsection{The declarative or isbati implicature}

Data 6 Episode 155

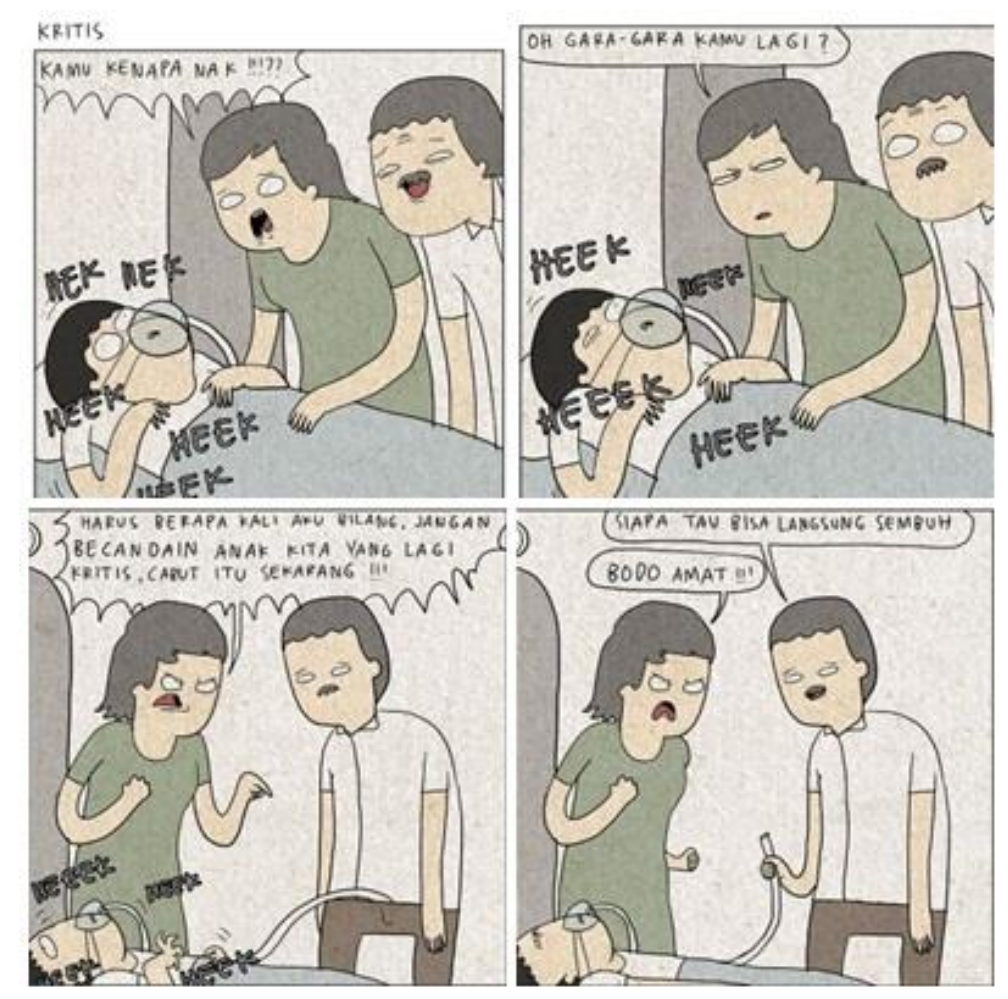
Context : The parents looked after their son, who was sick, in the hospital, and the son was in critical condition.
Mother : kamu kenapa nak??(1)
(what's happened, Son??)
oh gara-gara kamu lagi?(2)
(oh ... because of you ya?)
harus berapa kali aku bilang, jangan becandain anak kita yang lagi kritis, cabut itu sekarang!!! (3)
(How many times I tell you that don't joke our son. he has serious condition, remove it now!!!
Father $\quad$ : siapa tau bisa langsung sembuh (4)
(who knows he can heal immediately)
Mother : Bodo amat (5)
(Whatever!)

Parents looked after their son who was sick in the hospital. Suddenly his son has a critical condition because the father joked with his son. Then, his wife was angry with him because his son has a bad condition.

The conversation violated the quantity maxim. The mother asked the father why his son was in a critical condition, but the father unappropriately answered the mother's question. The conversation would work well if the participants obeyed the quantity maxim. Moreover, the sentence (3) "harus berapa kali aku bilang, jangan 
becandain anak kita yang lagi kritis, cabut itu sekarang!!!" has declarative implicature that the mother prohibited her husband to play with her son, who was critical. Thus, the implicature function to prohibit the husband.

For simplicity, here is a summary of the results of the analyses summarized in Table 1 . The recapitualtion of the data analysis. It is accompanied also by the maxim of the cooperation principle, and the form and function of the implicature of the conversation as follows:

Table 1. The recapitulation of data analysis

\begin{tabular}{|c|c|c|c|c|c|c|c|c|}
\hline \multirow{2}{*}{$\begin{array}{l}\text { No } \\
\text { Data }\end{array}$} & \multirow{2}{*}{ Episode } & \multicolumn{7}{|c|}{ The types and forms of Implicature } \\
\hline & & violation & Compliance & representative & directive & Expressive & commissive & Declarative \\
\hline 1 & 20 & Quantity & & explaining & begging & & & \\
\hline 2 & 27 & & Quality & & & beefing & & \\
\hline 3 & 54 & & Manner & & & & threating & canceling \\
\hline 4 & 123 & quantity & & & & & & Prohibiting \\
\hline 5 & 137 & Manner & & & & & & prohibiting \\
\hline 6 & 155 & & Manner & & & & & prohibiting \\
\hline 7 & 163 & & Quantity & Showing & $\begin{array}{l}\text { Suggesting } \\
\text { Asking }\end{array}$ & & & \\
\hline 8 & 165 & Relation & & & & beefing & & \\
\hline 9 & 220 & Manner & & explaining & & & & \\
\hline 10 & 235 & quality & & & Asking & & & \\
\hline 11 & 241 & Quantity & & & & & Threating & \\
\hline 12 & 244 & & Manner & & & complaining & & \\
\hline 13 & 280 & & Relation & & & & & deciding \\
\hline 14 & 309 & manner & & explaining & & & & \\
\hline 15 & 340 & Quantity & & & begging & & & \\
\hline 16 & 354 & Manner & & Showing & & & & \\
\hline 17 & 361 & Relation & & & ordering & & & \\
\hline 18 & 366 & & Relation & & & beefing & & \\
\hline 19 & 368 & Manner & & & & & Threating & \\
\hline 20 & 307 & Relation & & Explaining & & & & \\
\hline 21 & 377 & Quantity & & & begging & & & \\
\hline 22 & 388 & & Quantity & & & criticizing & & \\
\hline 23 & 397 & Manner & & & & criticizing & & \\
\hline 24 & 400 & Manner & & & & & & prohibiting \\
\hline 25 & 416 & Relation & & Showing & & & & \\
\hline 26 & 419 & Quality & & & & praising & & \\
\hline 27 & 426 & & Quantity & Showing & & & & \\
\hline 28 & 428 & & Relation & & & & & Prohibiting \\
\hline 29 & 452 & Relation & & & & praising & & \\
\hline 30 & 453 & Manner & & explaining & & & & \\
\hline Total & & 20 & 10 & 9 & 7 & 8 & 4 & 7 \\
\hline
\end{tabular}

The results of data analysis could be divided into two points: the cooperative principles, and the forms and functions of conversational implicature. The cooperative principles concern the violation of and compliance of maxims. There were 20 maxim violations and 10 data for the compliance of maxim. The second, the form and function of the conversational implicature, namely the representative form has 9 data which function as explaining and showing; the directive form has 7 data which function as begging, suggesting, asking, and ordering; the expressive form has 8 data functioning as beefing, complaining, criticizing, and praising; the commissive form has 4 data which function as threating and promising; and the declarative form has 7 data functioning as canceling, prohibiting, and deciding.

Based on the results, there are some points that can be explained. First, the use of the cooperative implicature can help to understand the speaker's meaning, whether it was a compliance or violation of the cooperative principle. The maxim of violation has 20 data that are 8 speeches for the manner maxim, 5 speeches for the relation maxim, 5 speeches for the quantity maxim and 2 speeches for the quality maxim. The maxim of compliance has 10 data that are 3 speeches for the quantity maxim, 3 speeches for the relation maxim, 3 speeches for the manner maxim and 2 speeches for the quality maxim. Through the violation and compliance of the maxims may illustrate the characteristics of the Tahilalats comic. The violation maxim is dominant in speech, so it can be interpreted that the setting of the speaker's information is not direct and unclear in Tahilalats comic. It can lead to misunderstanding in the interlocutor and can be used to generate humor. 
From the result of the data analysis in the form and function of conversational implicature, it was found that the implicature has 9 data in the representative from the highest data. The implicature is not explicitly expressed but implicitly expressed. The dominant function in Tahilalats comic was as explaining and showing a speech. They can be defined as describing or expressing or demonstrating something but it was the implicit context. However, the commissive implicature rarely appears in this comic. It can be concluded that the author used the implicature to describe and show the meaning. Through the violation or compliance of the cooperative principle, it can described that the implicatures contained in the conversation. The use of both can lead to humor by making the reader misunderstand when reading explicitly. After that, the reader will understand the implicit meaning.

\section{Conclusion}

After doing the data analysis about the cooperative principles and the conversational implicatures in Tahilalats comic. Understanding the use of the coopertaive principle can help to understand the conversational implicature. The meaning in Tahilalats comic contain the violation of the manner maxim which the information is deliberately made unclear. Moreover, the data refer to the representative implicature that has functions as the showing and explaining the truth of the implicature that contains in his/her speech. Thus, both of them show how the author's technique to present the humor in Tahilalats comic. This study only focuses on the use of cooperative principles and the coversational implicature. It is analyzed to understand the humor technique in Tahilalats comic. Thus, the discussion of the values or ideologies are reflected in the comic mainly comedy genres which can be a useful study in the future.

\section{References}

Brown, G., \& Yule, G. (1996). Discourse analysis. Cambridge: Cambridge University Press.

Grice, H. (1975). Logic and conversation. In p. Cole, \& J. Morgan (Eds.), Syntax and Semantics (pp. 41-58). New York: Academic Press.

Kazarian, S. S. (2011). The Humor in the collectivist Arab Middle East: The case of Lebanon. Walter de Gruyter, 24, 329-348.

Leech, G. (1993). Prinsip-prinsip Pragmatik. Jakarta: Universitas Indonesia (UI-Press).

Nandiwardana, A. (2016). Pelanggaran dan pematuhan prinsip kerjasama pada humor komik keruyon shinchan volume 3. Undergarduate Thesis, Universitas Diponegoro, Program studi S1 Sastra Jepang, Semarang.

Rani, A. (2006). Analisis Wacana. Jawa Timur: Banyu Media Publishing.

Rustono. (2000). Implikatur tuturan humor. Semarang : CV IKIP Semarang Press.

Saputri, N. I. (2013). Implikatur dan inferensi dalam buku humor anak sekolah karya drs. B.P Habeahan. Undergraduate thesis, Universitas Negeri Solo, Pendidikan Bahasa, Sastra Indonesia dan Daerah, Solo.

Sudaryanto. (1993). Metode dan aneka teknik analisis bahasa: Pengantar penelitian wahana kbudayaan secara linguistis. Yogyakarta: Duta Wacana University Press.

Suyono. (1990). Pragmatik dasar-dasar dan pengajaran. Malang: yayasan asih asah asuh (YA 3 Malang). 